\title{
Effect of dietary supplementation with Agaricus sylvaticus fungus on the hematology and immunology systems of breast cancer patients undergoing chemotherapy
}

\section{Agaricus sylvaticus mantarının besin takviyesi olarak kemoterapi gören meme kanserli hastaların hematolojik ve bağıșıklık sistemine etkisi}

\author{
Fabiana VALADARES ${ }^{1}$, Maria Rita Carvalho Garbi NOVAES ${ }^{2}$, Roberto Cañete VILLAFRANCA ${ }^{3}$ \\ Marília da Cunha MENEZES ${ }^{4}$, Mariana Campos REIS ${ }^{4}$, Daniella Rodrigues GONÇALVES ${ }^{4}$
}

\section{ÖZET}

Amaç: Kanser hastaları hastalığın seyri sırasında immünolojik ve hematolojik değișimler gelișmesine eğilimlidir. Tıbbi mantarlar, prognozda iyileșme ve fizyolojik yanıtı artırıcı etkiyle bağıșıklık ve hematopoetik sistemleri uyarabilirler. Bu çalıșmada Agaricus sylvaticus ile besin takviyesi sonrası kemoterapi gören meme kanserli hastalardaki hematolojik ve immünolojik parametrelerin değerlendirilmesi amaçlanmıștır.

Yöntem: Randomize seçilmiș, çift-kör, plasebo kontrollü bir çalıșma uygulanmıștır. 46 hastaya (grup II ve III) rastgele olarak ya plasebo ya da besin kaynağı olarak A. sylvaticus $(2,1 \mathrm{~g} / \mathrm{gün})$ verilmiștir. Hastalara 3 doz $(n=26)$ ve 6 doz kemoterapi uygulanmıs, klinik ve laboratuvar değerlendirmeleri yapılmıștır. Çalıșma sonuçları Microsoft Excel 2003 ve R-version 2.11.1 kullanılarak analiz edilmiş ve $\mathrm{p}<0.05$ olduğunda sonuçlar anlamlı kabul edilmiștir.

Bulgular: A. sylvaticus grubunun hematokrit $(p=0.04)$, kırmızı kan hücresi sayısı $(p=0.03)$, ortalama korpüsküler hemoglobin konsantrasyonu $(p=0.001)$, lökosit, monosit $(p=0.001)$ ve total lenfosit sayısı $(p=0.009)$ 'nda artıș görülmüștür. Bu gruptaki

\section{ABSTRACT}

Objective: Patients with cancer tend to develop hematological and immunological alterations during the disease process. Medicinal fungi can stimulate the immune and hematopoietic systems, promoting improvements in the prognosis and physiological response. In this trial it is aimed to evaluate changes in hematological and immunological parameters in patients with breast cancer undergoing chemotherapy after dietary supplementation with Agaricus sylvaticus.

Method: A randomized, double-blind, placebocontrolled study was carried out. 46 patients (stadiums II and III), were randomly assigned to receive either: nutritional supplement with $A$. sylvaticus $(2.1 \mathrm{~g} /$ day) or placebo. Patients received three cycles $(n=26)$ and six cycles $(n=20)$ of chemotherapy. Clinical and laboratory evaluations were performed. The results were analyzed using Microsoft Excel 2003 and R-version 2.11.1, significant results at $\mathrm{p} \leq 0.05$.

Results: The $A$. sylvaticus group showed an increase of hematocrits $(p=0.04)$, red blood count $(p=0.03)$, mean corpuscular hemoglobin concentration $(p=0.001)$, leukocytes $(p=0.03)$, monocytes $(p=0.001)$, and total lymphocyte count $(p=0.009)$ after three months. Those

\footnotetext{
${ }^{1}$ Clinical Nutrition Institute. University of Brasilia - DF. BRAZIL

2 School of Medicine. Institute of Health Science- ESCS; University of Brasilia - DF. BRAZIL

3 Centre for Hygiene, Epidemiology and Microbiology. Matanzas City, CUBA Cuban Institute of Gastroenterology. Havana City, CUBA

School of Medicine. Institute of Health Science- ESCS
} 
değișiklikler plasebo grubunda gözlenmemiștir. 6 ay sonra da $A$. sylvaticus alan hastalar total lenfosit sayısı (TLC) $(p=0.02)$, nötrofil $(p=0.02)$, lenfosit $(p=0.02)$, lökosit $(p=0.02)$, korpüsküler hemoglobin konsantrasyonu $(p=0.02)$, hematokrit $(p=0.02)$, hemoglobin $(p=0.02)$ ve kırmızı kan hücresi $(p=0.02)$ düzeyinde artış göstermiștir. Plasebo grubu TLC $(p=0.01)$ ve bazofil $(p=0.005)$ ve lökosit $(p=0.004)^{\prime}$ 'lerde azalma göstermiștir.

Sonuç: Çalıșma sonuçları kemoterapi alan meme kanserli hastalarda A. sylvaticus'un besin takviyesi olarak alımının faydalı olacağını önermektedir.

Anahtar Sözcükler: Hematolojik sistem, immun sistem, kemoterapi, A. sylvaticus

\section{INTRODUCTION}

Breast cancer is the most prevalent malignant cancer among women worldwide. Based on confidence data from the Brazilian Ministry of Health the experts estimate the existence of more than 49.000 new cases in Brazil annually both 2010 and 2011. Urbanization, increasing access to education and, health care is directly associated with improvement of breast cancer notification and management (1-3).

It is well known that treatment for breast cancer is complex and varies according to the histological diagnosis, age, clinical management, treatment, surgery and staging of the disease (4-6). Factors associated with tumor growth and chemotherapy can cause functional damage mainly in the hematological and immune systems of this patients.

It is important, additionally, to consider the side effects caused by conventional cancer treatments because could reduce significantly the caloric intake and absorption of nutrients, complicating treatment and reducing quality of life (7-11).

Chemotherapy is a treatment method widely used to treat breast cancer. The therapy aims at striking cell populations in different phases of the cell cycle, interfering with the reproduction, eliminating the hidden spread of the disease. However, during changes were not observed in the placebo group. After six months, patients receiving $A$. sylvaticus showed increased levels of red blood count $(p=0.02)$, hemoglobin $(p=0.02)$, hematocrits $(p=0.02)$, corpuscular hemoglobin concentration ( $p=0.02)$, leukocytes $(p=0.02)$; lymphocytes $(p=0.02)$, neutrophils $(p=0.02)$ and TLC $(p=0.02)$. The placebo group showed a reduction in leukocytes $(p=0.004)$, basophiles $(p=0.005)$ and TLC $(p=0.01)$.

Conclusion: The results suggest the usefulness of dietary supplementation with $A$. sylvaticus in patients with breast cancer undergoing chemotherapy.

Keywords: Hematological system, immune system, Chemotherapy, A. sylvaticus

treatment, chemotherapy can also destroy normal cells and cause serious side effects (7-8).

The most serious complication of chemotherapy is bone marrow suppression, with consequent worsening of hematological and immunological patterns that lead to systemic infection, coagulation disorders, amenorrhea and ovarian failure (6-11).

Different studies have suggested that the Agaricus sylvaticus mushroom, a fungus from the Agaricaceae family, has modulatory substances such as lectin, B-Glucan, proteoglucans, ergosterol, and arginine. The use of $A$. sylvaticus as adjuvant therapy to conventional treatment has showed promising results improving the quality of life of cancer patients (12-17).

The use of $A$. sylvaticus fungus as a dietary supplement in patients with various types of cancer has been studied (1-2). Although it's active mechanism is not clear yet (3), researchers have shown that the use of this mushroom acts to inhibit tumor growth and stimulate the hematological and immunological systems (12-17).

Experimental studies in animals and in vitro using cell lines of malignant breast cancer and other cancers have shown that preparations containing extracts of 
A. sylvaticus have favorable effects improving blood profile and immune response (17-29). Likewise, clinical studies in patients with breast cancer show a significant increase in red cell count and a change in host biological response by stimulating the immune system, preventing the proliferation of cancer cells, metastasis and the recurrence of malignant cells (30-36).

The aim of this study was to evaluate changes in hematological and immunological parameters of patients with breast cancer treated with conventional chemotherapy at the Oncology Clinic, Federal District Hospital - Brazil, after three and six months of dietary supplementation with fungi $A$. sylvaticus.

\section{MATERIAL AND METHODS}

\section{Study setting}

A randomized, double-blind, placebo-controlled trial was carried out at the Oncology Clinic of the Federal District Hospital in Brazil, from September 2007 to July 2009.

\section{Enrolment and subject selection}

The subjects were 46 women with breast cancer receiving chemotherapy treatment at the hospital; 26 undergoing three chemotherapy cycles and 20 undergoing six chemotherapy cycles.

Among women undergoing three chemotherapy cycles 14 were diagnosed in stadium II and 12 in stadium III. Of the patients undergoing 6 chemotherapy cycles 10 were located in stadium II and 10 in stadium III. Patients were separated in placebo group [(group of 3 cycles, $n=13$ ), (group of 6 cycles, $n=10$ )], and supplemented with $A$. sylvaticus fungus [group ( 3 cycles, $n=13$ ), (group of 6 cycles, $n=10$ )].

\section{Inclusion criteria}

Only women among 40 and 65 years old with breast cancer in stadiums II or III undergoing chemotherapy were included.

\section{Ethics}

The research process was approved by the Ethics Committee of the Ministry of Health of the Federal District, under protocol No. 041/2007. The enrolment also required that the agreement model were signed by patients, after being fully informed about the aim of the study and the characteristics of the product under investigation. The doctors signed the agreement model as well as the patients.

\section{A. sylvaticus extract}

The A. sylvaticus fungus, known popularly as Sun Mushroom- Cogumelo do Sol $\circledast$, was obtained from a producer accredited by Empresa Brasileira de Agropecuária- Embrapa, in Tapiraí Country, São Paulo state.

The fungus' extract was obtained by soaking the dried material in hot water for 30 minutes, liquefied, sieved and dried in a dissector. The composition analysis of $A$. sylvaticus was conducted by the Japan Food Research Laboratories Center, which revealed the presence of carbohydrates $(18.51 \mathrm{~g} / 100 \mathrm{~g})$, lipid $(0.04 \mathrm{~g} / 100 \mathrm{~g})$, ergosterol $(624 \mathrm{mg} / 100 \mathrm{~g})$, protein $(4.99 \mathrm{~g} / 100 \mathrm{~g})$, amino acids (arginine-1.14\% lysine- $1.23 \%$; histidine- $0.51 \%$, phenylalanine- $0.92 \%$, tyrosine- $0.67 \%$, leucine- $1.43 \%$, methionine- $0.32 \%$ valine $-1.03 \% \quad 1$-alanine, $28 \%$ glycine- $0.94 \%$ proline- $0.95 \%$, glutamic acid- $3.93 \%$, serine- $0.96 \%$, threonine- $0.96 \%$ acid aspart $-1.81 \%$, tryptophan- $0.32 \%$, cysteine- $0.25 \%$ ) and trace amounts of micronutrients.

The dry extract was processed into tablets according to pharmacotechnical procedure. The dosage of fungus administered to patients in the supplemented group was equivalent to $2.1 \mathrm{~g} /$ day, divided into three daily doses. The group of patients, who received placebo tablets, was administered the same quantities, with the same ingredients and calories, but without $A$. sylvaticus extract.

All patients ingested six tablets a day (two in the morning, two in the afternoon and evening, between meals) for a period of three and six months. 


\section{Clinical outcome}

A validated questionnaire, full physical exam and interview were used to assess patients. The questionnaire was applied on the first day. In subsequent appointments directed interviews were carried out. All data were collected by trained researchers.

Up to six laboratory tests of complete patient blood count were carried out: immediately before and after supplementation. Blood collection was performed following the criterion of $12 \mathrm{~h}$ fasting. The collected material was deposited in dry vacuum tubes to obtain serum, following protocols recommended by the Brazilian Society of Pathology for venous blood collection. The examinations were performed at the Clinical Pathology Laboratory, Base Hospital, Ministry of Health-Federal District, and analyzed according to standardized reference values utilized by this institution.

Regarding Complete Blood Count (CBC), the samples were centrifuged and the analysis performed in COULTER T-540 manufactured in 1988, according to laboratory routine. The determination of the analysis followed the principle of flow cytometry, using the following reagents: isotonic (diluents), litic (Hemolysing erythrocytes) and clean Coulter (detergent used in washing the machine).

All patients were contacted weekly by researchers, via telephone, to classify doubts, check the appropriate use of mushroom according to guidelines and confirm appointments, thus ensuring greater adherence to treatment and control over the continuity of study.

Dropout patients were considered those who only attended the first consultations or did not attend consultations during the three months or underwent less than four tests. Mushrooms were made available to patients who wished to use mushroom supplementation after the end of study.

\section{Statistical Analysis}

Patients were separated into groups of three and six chemotherapy cycles and later on in placebo and A. sylvaticus groups in order to compare results. All collected data were analyzed as qualitative and descriptive, using Microsoft Excel 2003 for database and statistical software R: Regulatory Compliance and Validation Issues for statistical analysis, version 2.11.1.

\section{RESULTS}

After six months of attendance at the Oncology Clinic of the Federal District Hospital, 46 patients with breast cancer completed the study; they were separated according to chemotherapy cycles and later on placebo or study groups.

\section{Results of Patients with three chemotherapy cycles}

Patients with three chemotherapy cycles after allocation into placebo or study groups presented the following results: placebo $(n=13)$ had a mean age of $50.61 \pm 6.65$ years. Regarding stadium, 61.5\% ( $n=8)$ were in stadium II $38.5 \%(\mathrm{n}=5)$ in stadium III. Patients supplemented with $A$. sylvaticus $(\mathrm{n}=13)$ had mean age of $53 \pm 5.4$ years. As for stadium, $46.2 \%(n=6)$ were in stadium II and $53.8 \%(n=7)$ in stadium III of disease.

Placebo group showed a significant decrease in serum levels of red blood cells, monocytes and lymphocytes count. In group receiving $A$. sylvaticus, there was a significant increase in red blood cell count, hematocrit, corpuscular hemoglobin concentration, leukocyte, monocytes and total lymphocyte count after three months of supplementation (Table 1).

When comparing the first and third months of chemotherapy, considering reference values from 3.9 to $5.03 / \mathrm{mm}^{3}$ for evaluation of red blood cells, the placebo group showed significant decrease (from $4.47 \pm 0.04 / \mathrm{mm}^{3}$ to $4.14 \pm 0.53, \mathrm{p}=0.02$ ), while the supplemented group showed significant blood cell increase (of $4: 31 \pm 0.29 / \mathrm{mm}^{3}$ to $4.76 \pm 0.58, \mathrm{p}=0$, 2003) (Table 1). 
Table 1. Results of red blood cell count series for patients in the placebo group and Agaricus sylvaticus with three chemotherapy cycles

\begin{tabular}{|c|c|c|c|c|c|c|c|}
\hline \multirow{2}{*}{ Red Series } & \multicolumn{3}{|c|}{ Placebo $(n=13)$} & \multicolumn{3}{|c|}{ Agaricus sylvaticus $(\mathrm{n}=13)$} & \multirow{2}{*}{ Reference value } \\
\hline & Initial & Three months & $\mathrm{p}$-value * & Initial & Three months & $\mathrm{p}$-value * & \\
\hline $\begin{array}{l}\text { Hemoglobin } \\
\text { (g/dL) }\end{array}$ & $12.66 \pm 0.77$ & $12.08 \pm 1.07$ & 0.12 & $11.9 \pm 1.41$ & $12.09 \pm 1.23$ & 0.07 & 12 to $15.5 \mathrm{~g} / \mathrm{dl}$ \\
\hline $\begin{array}{l}\text { Hematocrit } \\
(\%)\end{array}$ & $36.99 \pm 3.24$ & $34.60 \pm 3.21$ & 0.10 & $34.29 \pm 4.17$ & $37.46 \pm 2.34$ & 0.04 & $35-45 \%$ \\
\hline $\begin{array}{l}\text { RBC } \\
\left(10^{6} / \mathrm{m} \mu \mathrm{L}\right)\end{array}$ & $4.47 \pm 0.44$ & $4.14 \pm 0.53$ & 0.02 & $4.31 \pm 0.29$ & $4.76 \pm 0.58$ & 0.03 & 3.9 to $5.0010^{6} / \mathrm{m} \mu \mathrm{L}$ \\
\hline $\begin{array}{l}\text { MCV } \\
\text { (Ft) }\end{array}$ & $82.62 \pm 6.58$ & $89.49 \pm 4.59$ & 0.40 & $4.13 \pm 86.36$ & $87.04 \pm 4.04$ & 0.64 & $82-98 \mathrm{fL}$ \\
\hline $\begin{array}{l}\mathrm{MCH} \\
(\mathrm{pg})\end{array}$ & $29.55 \pm 3.09$ & $31.32 \pm 5.44$ & 0.40 & $29.38 \pm 3.58$ & $30.99 \pm 3.31$ & 0.15 & $26-34 \mathrm{pg}$ \\
\hline $\begin{array}{l}\mathrm{MCHC} \\
(\mathrm{g} / \mathrm{dL})\end{array}$ & $34.55 \pm 3.81$ & $33.67 \pm 1.72$ & 0.40 & $32.46 \pm 1.11$ & $34.94 \pm 2.1$ & 0.001 & $31-36 \mathrm{~g} / \mathrm{dL}$ \\
\hline
\end{tabular}

T-student tests applied. The values represent sit mean \pm standard deviation

* Comparison between baseline and after three months

Hemoglobin levels of both groups were no significant considering reference values from 12 to $15.5 \mathrm{~g} / \mathrm{dL}$, however there was a slight hemoglobin increase for the group supplemented with A. sylvaticus (placebo group: $1266 \pm 0.77$ to 12.08 $\pm 1.07, p=0.12$; study group: $11.9 \pm 1.41$ to $12.9 \pm$ 1.23, $p=0.07$ ) (Table 1). There was a significant increase in hematocrits value of group $A$. sylvaticus (from $34.29 \pm 4.17$ to $37.46 \pm 2.34, p=0.04$ ). For placebo group no significant value was found (from $36.99 \pm 3.24$ to $34.60 \pm 3.21, p=0.1$ ) (Table 1).

By analyzing hematological parameters, rates of Mean Corpuscular Volume (MCV), mean corpuscular hemoglobin $(\mathrm{MCH})$ showed statistically significant increase for both groups, the MCV values found for the placebo group and $A$. sylvaticus respectively: from $88.62 \pm 6.58$ to $89.49 \pm 4.59$, $\mathrm{p}=0.46$, and $86.36 \pm 4.13$ to $87.04 \pm 4.04$, $\mathrm{p}=0.64$; and $\mathrm{MCH}$ values for the placebo group and $A$. sylvaticus: from $29.55 \pm 3.09$ to $31.32 \pm 5.44$, $p=0.41$ and $29.38 \pm 3.58$ to $30.99 \pm 3.31, p=0.15$, respectively (Table 1 ).
In relation to values of mean corpuscular hemoglobin concentration (MCHC) there was a significant difference for the $A$. sylvaticus group. There was an increase in $\mathrm{MCHC}$ values when comparing the first and last months of supplementation (from 32.46 \pm 1.11 to $34.94 \pm 2.1, p=0.001$ ). As for the placebo group there was no significant decrease (from $34.55 \pm$ 3.81 to $33.67 \pm 1.72, p=0.45$ ) (Table 1$)$.

Regarding immunological parameters, the number of white blood cells was observed. There was a significant increase in the number of leukocytes (5.07 \pm 1.54 to $5.9 \pm 1.90, p=0.03$ ) for the $A$. sylvaticus group. Findings in the placebo group showed a slight decrease, but revealed no significant difference $(5.28 \pm 1.70$ to $4.36 \pm 1.55, p=0.26)$. Observed reference values were 3.5 to $10.5 / \mathrm{mm}^{3}$ (Table 2).

The values of myeloid elements found revealed a significant increase only in the number of monocytes for group $A$. sylvaticus $(5.67 \pm 1.767 .007 \pm 1.41$, $\mathrm{p}=0.001)$ and placebo $(5.59 \pm 1.50$ to $7.89 \pm 2.46$, $p=0.01$ ). Regarding neutrophiles, eosinophiles, and basophiles there was no significant difference for both groups (Table 2 ). 
Regarding lymphocyte percentages, there was no significant difference for both groups, however, for total lymphocyte count (TLC) there was a significant difference in the placebo groups with significant reduction of data $(1738.45 \pm 7441115.15 \pm 218$ for, 16, $\mathrm{p}=0.01$ ) and for the $A$. sylvaticus group a significant increase was revealed (from $1454.32 \pm$ 381.47 to $1931.39 \pm 649.60, \mathrm{p}=0.009$ ) (Table 2).

Platelets showed no significant values for the placebo or the A. sylvaticus group. However platelets presented a slight decrease for the supplemented group (281 \pm 38.02 to $249 \pm 47.8, p=0.06)$, upon comparing the first and third months of follow up (Table 2).

\section{Outcome of Patients with six chemotherapy cycles}

After six months of attendance at the Oncology Clinic, 20 patients with breast cancer completed the study, which were separated into placebo or study group (A. sylvaticus).

Patients in the placebo group $(n=10)$ had mean age of $48.2 \pm 3.64$ years. With regards to stadium, $30 \%(n=3)$ were in stadium II 70\% $(n=7)$ in stadium III. Patients receiving $A$. sylvaticus $(n=10)$ had a mean age of $52.3 \pm 5.86$ years. As for stadium, $40 \%(n=4)$ were in stadium II and $60 \%(\mathrm{n}=6)$ in stadium III of disease.

Data analysis was performed on two times. Initially first and third month's chemotherapy was compared. After that a comparative analysis was performed between the first and sixth month of observation. This evaluation was performed for placebo and A. sylvaticus groups.

Regarding CBC results, the group supplemented with $A$. sylvaticus, showed significant levels of red blood cells, hemoglobin, hematocrit, mean

Table 2. Results of white blood cell counts for patients in the group and Agaricus sylvaticus with three chemotherapy cycles

\begin{tabular}{|c|c|c|c|c|c|c|c|}
\hline \multirow[b]{2}{*}{$\begin{array}{l}\text { White } \\
\text { Series }\end{array}$} & \multicolumn{3}{|c|}{ Placebo $(n=13)$} & \multicolumn{3}{|c|}{ Agaricus sylvaticus $(n=13)$} & \multirow[b]{2}{*}{$\begin{array}{l}\text { Reference } \\
\text { value }\end{array}$} \\
\hline & Initial & Three months & $\dot{2} \frac{*}{\frac{0}{J}}$ & Initial & Three months & 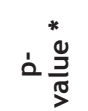 & \\
\hline $\begin{array}{l}\text { Leukocytes } \\
\left(/ \mathrm{mm}^{3}\right)\end{array}$ & $5.28 \pm 1.70$ & $4.36 \pm 1.55$ & 0.2 & $5.07 \pm 1.54$ & $5.92 \pm 1.90$ & 0.03 & $\begin{array}{c}10.5 \pm 3.5 \\
/ \mathrm{mm}^{3}\end{array}$ \\
\hline $\begin{array}{l}\text { Lymphocytes } \\
\text { (\%) }\end{array}$ & $32.57 \pm 6.47$ & $27.47 \pm 8.68$ & 0.10 & $29.99 \pm 6.09$ & $33.12 \pm 4.83$ & 0.10 & $20-35 \%$ \\
\hline $\begin{array}{l}\text { CTL } \\
\left(/ \mathrm{mm}^{3}\right)\end{array}$ & $1738.45 \pm 744.08$ & $1115.15 \pm 218.16$ & 0.01 & $1454.32 \pm 381.47$ & $1931.39 \pm 649.6$ & 0.009 & $\begin{array}{c}1200-2000 \\
/ \mathrm{mm}^{3}\end{array}$ \\
\hline $\begin{array}{l}\text { Neutrophiles } \\
\text { (\%) }\end{array}$ & $50.86 \pm 9.84$ & $47.33 \pm 4.71$ & 0.20 & $52.5 \pm 10.69$ & $58.56 \pm 6.86$ & 0.10 & $40-80 \%$ \\
\hline $\begin{array}{l}\text { Monocytes } \\
\text { (\%) }\end{array}$ & $5.59 \pm 1.5$ & $7.89 \pm 2.46$ & 0.01 & $5.67 \pm 1.76$ & $7.0 \pm 1.41$ & 0.01 & $3-9 \%$ \\
\hline $\begin{array}{l}\text { Eosinophiles } \\
\text { (\%) }\end{array}$ & $2.46 \pm 0.87$ & $2.69 \pm 0.85$ & 0.38 & $2.69 \pm 0.85$ & $2.84 \pm 0.98$ & 0.60 & $1-5 \%$ \\
\hline $\begin{array}{l}\text { Basophiles } \\
(\%)\end{array}$ & $0.69 \pm 0.48$ & $0.61 \pm 0.5$ & 0.50 & $0.69 \pm 0.48$ & $0.61 \pm 0.5$ & 0.60 & $0-1 \%$ \\
\hline $\begin{array}{l}\text { Platelets } \\
\left(10^{3} / \mathrm{mm}^{3}\right)\end{array}$ & $248 \pm 48.7$ & $285 \pm 63.71$ & 0.10 & $281 \pm 38.02$ & $249 \pm 47.8$ & 0.06 & $\begin{array}{l}150-450 \\
10^{3} / \mathrm{mm}^{3}\end{array}$ \\
\hline
\end{tabular}

T-student tests applied. The values represent the sit mean \pm standard deviation

* Comparison between baseline and after three month 
corpuscular hemoglobin (MCH), leukocytes, lymphocytes, neutrophils and total lymphocytes (TLC) after six months of supplementation. The placebo group showed a significant decrease in serum levels of erythrocytes, leukocytes, basophiles and CTL (Table 3).

When comparing the first and third month of chemotherapy, considering reference values from 3.9 to $5.0310^{6} / \mathrm{m} \mu \mathrm{L}$, to assess the number of red blood cells, the placebo group showed a significant decrease (from $4.21 \pm 0,5510^{6} / \mathrm{m} \mu \mathrm{L}$ to $3.94 \pm 0.66$ $10 \mathrm{6} / \mathrm{m} \mu \mathrm{L}, \mathrm{p}=0.02$ ). As for values observed in the sixth month of treatment, there was a decrease in the number of red blood cells $(4.21 \pm 0.55$ to 3.63 $\pm 0.3310^{6} / \mathrm{m} \mu \mathrm{L}, \mathrm{p}=0.03$ ). The group supplemented with $A$. sylvaticus revealed a significant increase in the number of red blood cells for the third month of supplementation (from $1.18 \pm 4: 23 \quad 10^{6} / \mathrm{m} \mu \mathrm{L}$ to $4.6 \pm 0.910^{6} / \mathrm{m} \mu \mathrm{L}, \mathrm{p}=0.0007$ ) and for the sixth month of supplementation (from $1.18 \pm$ 4:23 $10^{6} / \mathrm{m} \mu \mathrm{L}$ to $5.01 \pm 0.510^{6} / \mathrm{m} \mu \mathrm{L}, \mathrm{p}=0.0008$ ) when compared to the first month of treatment (Table 3).

In relation to hemoglobin level assessed in both periods, the $A$. sylvaticus group presented significant results showing increase in hemoglobin parameters of reference values from 12 to $15.5 \mathrm{~g} / \mathrm{dL}(12.04 \pm 1.2$ $\mathrm{g} / \mathrm{dL}$ to $12.61 \pm 1.27 \mathrm{~g} / \mathrm{dL}, \mathrm{p}=0.01$ - the third month, $12.4 \pm 1.2 \mathrm{~g} / \mathrm{dL}$ to $13.17 \pm 1.29 \mathrm{~g} / \mathrm{dL}, \mathrm{p}=0.01$ - the sixth month). The placebo group showed no significant result in hemoglobin parameters (from $12.22 \pm 1.32$ $\mathrm{g} / \mathrm{dL}$ to $11.52 \pm 1.98 \mathrm{~g} / \mathrm{dL}, \mathrm{p}=0.08$ and $12.22 \pm 1.32$ $\mathrm{g} / \mathrm{dL}$ to $11.68 \pm 1.66 \mathrm{~g} / \mathrm{dL}, \mathrm{p}=0.02$, respectively for three and six months of supplementation (Table 3).

Hematocrit analysis revealed a significant increase in the percentage of the $A$. sylvaticus group in the third month of supplementation (from $36.44 \pm 3.06 \%$ to $38.7 \pm 3.41 \%, p=0.02$ ). There were no significant values for the placebo group (Table 3).

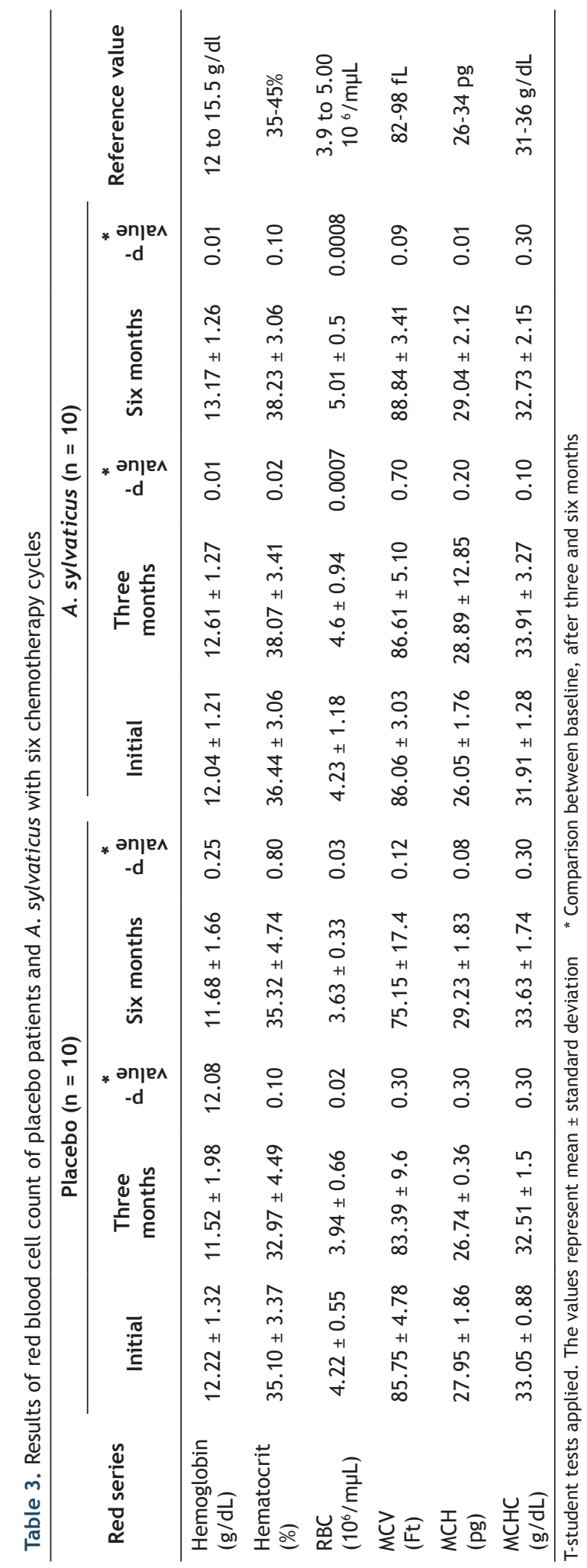


Analyzing the hematimetric rates of Mean Corpuscular Volume (MCV), Mean Corpuscular Hemoglobin $(\mathrm{MCH})$ and Mean Corpuscular Hemoglobin Concentration (MCHC), showed no statistically significant decrease during the treatment period in the placebo group; $\mathrm{MCH}$ values (from $26.05 \pm 1.76 \mathrm{pg}$ to $29.04 \pm 2.12 \mathrm{pg}, \mathrm{p}=0.01$ ) found for the $A$. sylvaticus group showed statistical significance in the last month of supplementation; regarding MCV and $\mathrm{MCHC}$ values a slight, yet irrelevant, increase was seen (Table 3).

With respect to immunological parameters, the white blood cells count series was observed. Regarding leukocyte numbers, there was a significant increase in the last month of supplementation for the A. sylvaticus group $\left(4.7 \pm 1.4 / \mathrm{mm}^{3}\right.$ to $5.95 \pm 1.23$ $\left./ \mathrm{mm}^{3}, \mathrm{p}=0.008\right)$. Compared to the placebo group, there was a significant reduction in the number of leukocytes in the third month of supplementation $\left(4.51 \pm 1.05 / \mathrm{mm}^{3}\right.$ to $\left.3.14 \pm 055 / \mathrm{mm}^{3}, \mathrm{p}=0.004\right)$. Observed reference values were 3.5 to $10.5 / \mathrm{mm}^{3}$ (Table 4).

The percentage values of myeloid elements found for the $A$. sylvaticus group revealed significant results in the number of neutrophils (from $46.17 \pm 13.19 \%$ to $54.5 \pm 10.3 \%, p=0.01$ ). For the placebo group, there was but a significant decreases in the percentage of basophiles $(0.8 \pm 0.4 \%$ to $0.2 \pm 0.4 \%, p=0.005)$. As for data on eosinophiles and monocytes, neither group showed any difference (Table 4).

Regarding lymphocyte percentage, there was no significant difference in both periods observed for the placebo group. In relation to the $A$. sylvaticus group there was significant increase in both periods $(24.25$ $\pm 2.34 \%$ to $29.88 \pm 4.16 \%, p=0.01$ - third month, 24.25 $\pm 2.34 \%$ to $29.7 \pm 3.26 \%, p=0.0004$ - sixth month). In relation to TLC the $A$. sylvaticus group showed significant results only during the sixth months of research, revealing values of $1152.5 \pm 431.5 / \mathrm{mm}^{3}$ to $1761 \pm 376.8 / \mathrm{mm}^{3}, p=0.003$. Compared to the placebo group, results were significant only in the third month of the survey which showed the following values: from $1384.6 \pm 405.88 / \mathrm{mm}^{3}$ to $896.98 \pm 185.4$ $/ \mathrm{mm}^{3} \mathrm{p}=0.01$ (Table 4).

Platelets showed no significant values for the placebo group or the $A$. sylvaticus group in relation to the survey follow-up period (Table 4).

\section{DISCUSSION}

Patients with breast cancer often have hematological and immunological alterations during the disease process. Drugs used in chemotherapy induce bone marrow depression impairing the body's defenses to fight the disease itself depriving patients with malignant neoplasm of quality of life (8-9). Bone marrow cells renew quickly and, therefore, are very susceptible to the action of chemotherapeutic agents and other factors related to tumor development, which can lead to leucopenia, granulocytopenia, thrombocytopenia, and anemia (6, 11-36).

The toxicity of chemotherapy in hematological profile is expressed on three medullar lines: red cells, platelets and leucocytes. Because of the erythrocytes half-life, the development of anemia is belated. The concentration of the hemoglobin is related to red blood cells count and is used to monitor therapy response (8-11).

In the current study, with respect to the blood count of patients undergoing three chemotherapy cycles, data analysis revealed a significant increase in hematocrit serum levels $(p=0.04)$, and hemoglobin $(p=0.03), M C H C(p=0.001)$ in the group treated with A. sylvaticus after three months of supplementation. These findings were not observed in patients included in the placebo group which showed a significant reduction $(p=0.02)$ in the number of red blood cells (Table 1 and 2).

Regarding $\mathrm{CBC}$, the results observed for patients undergoing six chemotherapy cycles in group supplemented with $A$. sylvaticus showed relevant levels of red blood cells $(p=0.02)$, hemoglobin $(p=0.02)$, hematocrit $(p=0.02), M C H \quad(p=0.02)$, leukocytes $(p=0.02)$, lymphocytes $(p=0.02)$, neutrophils $(p=0.02)$ 


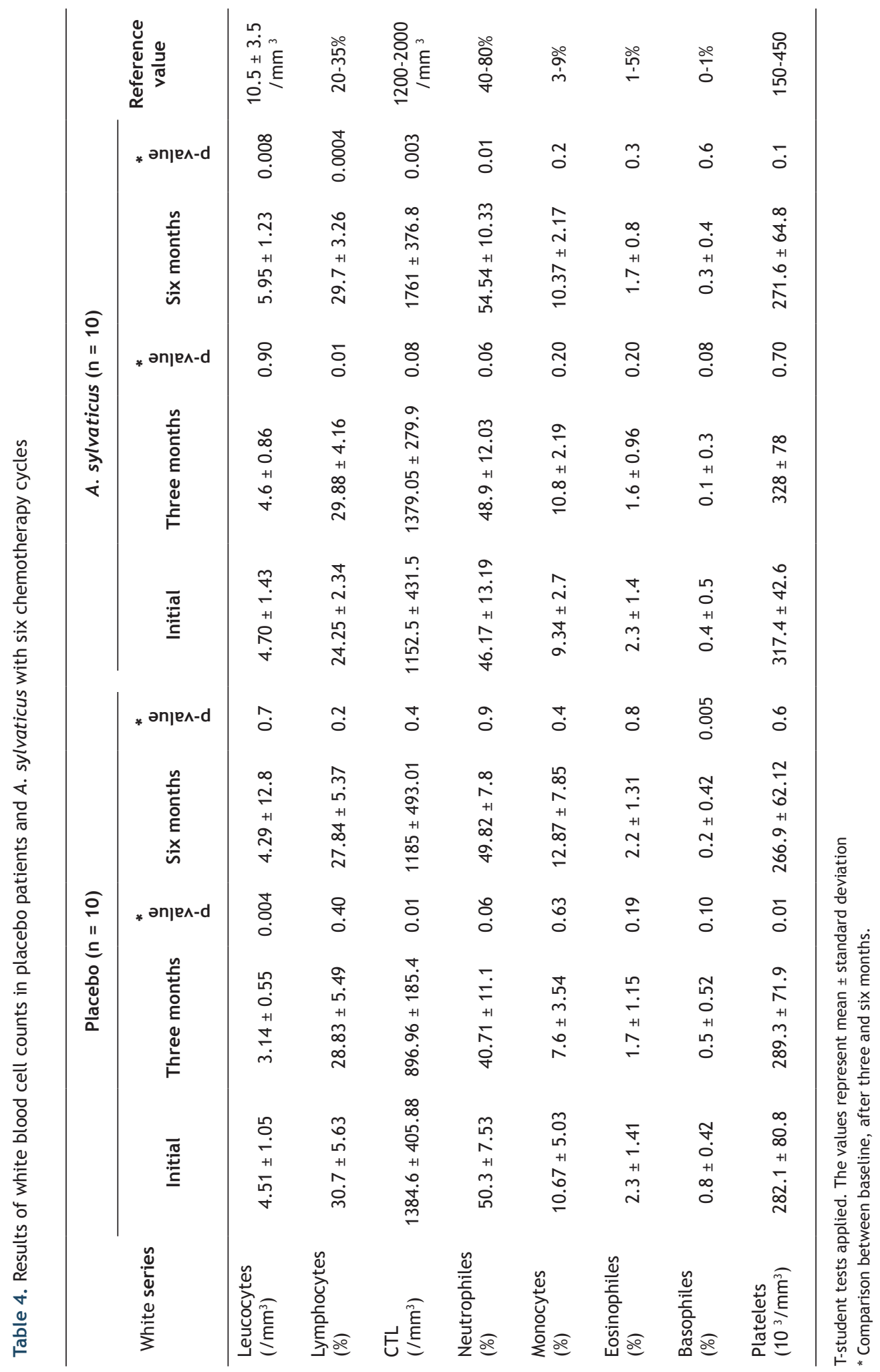


and TLC ( $p=0.02)$ after six months of supplementation. The placebo group showed a significant reduction in serum levels of red blood cells $(p=0.02$ and $p=0.03)$, leukocytes $(p=0.004)$, basophiles $(p=0.005)$ and TLC $(\mathrm{p}=0.01)$ (Table 3 and 4).

Concerning $\mathrm{CBC}$, patients undergoing three chemotherapy cycles in the placebo group showed decreased values in all analyzed patterns. However, only the number of erythrocytes was significant $\left(3^{\text {rd }}\right.$ month- $p=0.02$ ) upon completion of three month supplementation. The same result was observed in patients undergoing six chemotherapy cycles, which showed a significant decrease for the two periods observed ( $3^{\text {rd }}$ month- $p=0.02$ and 6th month- $p=0.03$ ). In relation to hematimetric values, patients in both groups (3/6 cycles-placebo) revealed no significant decrease.

The red series of patients supplemented with A. sylvaticus for three months, upon completion of treatment showed an increase in blood cells $(p=0.03)$, in hematocrit percentage $(p=0.03)$ and MCHC $(p=0.001)$. Similar results were observed in the third month of treatment in patients undergoing six chemotherapy cycles, besides an increase in hemoglobin values $(p=0.01)$. Upon conclusion of treatment, supplement patients undergoing six therapy cycles, demonstrated significant increases in blood cells $(p=0.0008)$, hemoglobin $(p=0.01)$ and $\mathrm{MCH}$ $(p=0.01)$. As for the hematocrits rate, there was no significant increase of values found after six months of supplementation; some significance was seen only in the third month of the research segment. Regarding hematimetric values, although there was an increase in observed values, these were not significant in both groups.

Fortes et al (31) in randomized placebo-controlled, double-blind clinical trial evaluated the effects of supplementation with $A$. sylvaticus extracts in cancer patients undergoing chemotherapy, where the supplemented group showed significant hematocrits and red blood cell increase, and no significant increase in hemoglobin, $M C H, M C V$, revealing the possible benefits on the hematological system.

Novaes et al. (17) in a prospective, randomized, blind, placebo-controlled study evaluated the effects of the administration of $A$. sylvaticus extracts in rats with Walker 256 ascitic tumor and observed significant improvement in hematologic and immune functions, where the probable mechanism of action is the inhibition of tumor growth and stimulation of the hematological and immunological systems.

Dolby et al. (32) reported that the D-fraction of the B-Glucan found in medicinal mushroom of the Agaricaceae family such as $A$. sylvaticus, had a positive effect on the health status of women diagnosed with breast cancer. There was an improvement in clinical parameters and laboratory tests showed improvement in the hematological system, further to reducing vomiting caused by chemotherapy, increasing appetite of patients, reducing anorexia which can also be a side effect of conventional treatments (25).

See et al. (33) in a clinical study of various types of cancers including breast cancer (stadium IV), provided the patients with immunomodulatory components complex, among them Agaricus blazei tea $(10 \mathrm{mg} /$ day). Six months after starting treatment, some patients had increased NK cells activity (Natural Killer), levels of TNF-a (tumor necrosis factor), of erythrocytes, hemoglobin and glutathione. The receptors for TNF-a had decreased. Diarrhea and occasional nausea were reported, but quality of life had improved. The combination of immune active components was effective in increasing NK cells function and other immunological parameters in patients in advanced stages of cancer, thus enabling the effectiveness of a nutritional combination in the treatment of late stages of cancer (24).

The data from this study suggest that there is evidence which indicates the presence of bioactive compounds in $A$. sylvaticus fungi capable of acting positively on the hematological system in patients 
with breast cancer. By observing the reported data, it appears that there was improvement in clinical parameters of red series in all periods of the study, regardless the degree of significance.

The analysis of white blood cell count in patients undergoing three chemotherapy cycles, who were supplemented with $A$. sylvaticus showed a significant increase in parameters for leukocytes $(p=0.03)$, monocytes $(p=0.01)$ and TLC $(p=0.009)$ after 3 months of segment. Patients undergoing six chemotherapy cycles revealed a significant increase in lymphocytes parameters $(p=0.01)$ in the first quarter of the survey, other immunological parameters showed increase, but with no statistical relevance. After six months of supplementation the $A$. sylvaticus group revealed significant values for leukocytes $(p=0.008)$, lymphocytes $(p=0.0004)$, TLC $(p=0.003)$ and neutrophils $(p=0.01)$, other parameters were not significant during the research period.

Statistically significant findings in the placebo group undergoing three cycles of treatment were the decrease in numbers of monocytes $(p=0.01)$ and TLC $(p=0.01)$. Other parameters did not show statistical relevance despite being reduced. In relation to patients of the placebo group with six chemotherapy cycles, statistically relevant findings for the first quarter of survey revealed a decrease in leukocyte numbers $(p=0.004)$ and TLC $(p=0.01)$. Other parameters showed no statistical relevance, despite being slightly decreased. After six months of research the placebo group also showed decreased values in relation to the first month of supplementation, however, only the percentage of basophils $(p=0.005)$ showed significant decrease.

Scientific evidence indicates that dietary supplementation with medicinal fungi such as A. sylvaticus is capable of significantly improving the physiological condition and prognosis of cancer patients (30-36).

Research with medicinal mushrooms indicate that $\beta$-glucan polysaccharide acts in the body by increasing immune functions, stimulating and activating NK cells, T lymphocytes, B lymphocytes and complementary cells, with consequent increase in the number of macrophages and monocytes, in addition to promoting proliferation and/or production of antibodies and various cytokines such as interleukins 2 and 6, INF- $\gamma$ and TNF-a (12-17).

The $\beta$-glucan bind to receptors on macrophages membranes, neutrophils, NK cells, T cells, dendritic cells, fibroblasts and vascular endothelial cells. The molecular structure of these substances influences their affinity for the receptors. These receptors have been described as phagocytic receptors for antigens. Research carried out with $\beta$-glucan extracted from fungi proved that these act by stimulating the action of neutrophils, eosinophils, monocytes, macrophages and NK cells via their specific receptors (17). However, the exact active mechanism of this polysaccharide is not yet fully elucidated. These components can regulate various aspects of humoral and/or cellular components of the immune system. Padilha et al (37) observing the action of $\beta$-glucan from Agaricales mushrooms extracts reported the possibility of this substance to reduce the inflammatory process of diseases by stimulating the immune system, increasing the number of defense cells.

Clinical studies show that the combination of reduced eosinophils and basophiles count in patients with cancer is a common finding. These changes may occur owing to direct action of tumor presence. Moreover, the decrease in lymphocyte count is also associated with more aggressive tumor behavior (14).

Takimoto et al. (18) in a randomized clinical trial orally administered Agaricus blazei extract in rats. The control group was treated orally with water. The study showed an increase in NK cells and increment in cytotoxic $T$ lymphocytes. The research indicates that the mushroom extract potentializes innate and adaptive immunological cytotoxic activity (10). 
Gennari et al $(34,35)$ in two studies on women diagnosed with breast cancer, noted that dietary supplementation with $A$. sylvaticus, could stimulate the immune system increasing the number of NK cells and CD 56+.

Leucopenia, neutropenia and lymphocytopenia are the main immunological changes seen in studies on chemotherapy. Aguiar (36) in a study carried out with women in stadiums II and III of breast cancer undergoing chemotherapy and supplementation with arginine found an improvement in the numbers of leukocytes, lymphocytes and neutrophils after three months of supplementation and chemotherapy.

Fortes et al (17) evaluated the immune function of cancer patients after supplementation with A. sylvaticus during a period of three months and observed a significant increase in leukocyte count, lymphocytes, and basophiles TLC and non-significant reduction of monocytes, eosinophils and neutrophils in the supplemented group reaching reference values. In the placebo group no alterations were observed. The authors concluded that a dietary supplementation with $A$. sylvaticus is capable of significantly increasing the immunity of cancer patients. Similar results were observed in those groups reported in this study.

Factors related to tumor development in patients with cancer can be blamed on platelet increase. It is believed that reactive thrombocytosis commonly observed in patients with cancer can be justified by this rise in platelet. However, the deleterious effects caused by chemotherapy may emerge as a protective factor against this excessive augment of platelets, reducing their production. Aguiar (36) found that patients with breast cancer maintained platelet values preserved within the normal range after three months of supplementation with arginine. Fortes et al observed a significant reduction in platelet count for the group supplemented with $A$. sylvaticus. Yet, both groups remained within the normal range, suggesting that $A$. sylvaticus is capable of preventing thrombocytosis in patients with malignant neoplasia.

In this study, as related in the literature, the platelet count remained at normal levels in both groups. A significant increase in platelet count was observed in the placebo group patients with three chemotherapy cycles $(p=0.01)$ after three months of treatment. However, in other groups the increase was not significant. In the group supplemented with A. sylvaticus, a reduction of platelets was observed when compared to the group that received placebo, however, these values were not significant. The data found in the research show the possible action of the A. sylvaticus fungus in controlling platelet production, suggesting the prevention of thrombocytosis in patients with malignant neoplasia.

Factors such as dose, rate, duration and frequency of supplementation, further to the active mechanism, interfere with the ability of the bioactive compounds present in medicinal fungi to improve or suppress the immune response of patients. Few studies have been conducted in relation to the pharmacological effects of these substances. In vivo studies have revealed that extracts of certain fungi do not have significant effects on patients with normal hematologic and immunologic profile, although they have the ability to restore the impaired immune response due to tumors, reaching normal levels (19). All these factors may explain, though in part, results found in red and white cells count of patients supplemented with $A$. sylvaticus in this study.

The mechanism of action of these fungi and their bioactive molecules in cancer therapy need to be better clarified; nevertheless, research has shown that many of these substances exert an anticarcinogenic, antiviral, antithrombotic, antibiotic and antiinflammatory further to many more functions that provide health benefits (12-17). 


\section{CONCLUSION}

The hematological and immunological effects of medicinal mushrooms reported in several clinical and experimental published studies, have shown promising results when used as an adjuvant element in breast cancer treatment. Nevertheless, new protocols to conduct clinical trials are needed to elucidate the possible active mechanisms and clinical benefits of these fungi in various types of cancer.

\section{KAYNAKLAR}

1. Brazil. Ministério da Saúde. Secretaria Nacional de Assistência à Saúde. Instituto Nacional do Câncer [INCA]. Estimate 2010: Cancer Incidence in Brazil. Rio de Janeiro: INCA 2009. Brazil.

2. Tiezzi DG. Epidemiology of breast cancer. Rev Bras Obstetr Ginecol. 2009; 3(5): 213-5.

3. Guerra MR, Gallo CVM, Mendonça GAS. Risk of cancer in Brazil: trends and recent epidemiological studies. Rev Cancer Brazil, 2005; 51(3):227- 34.

4. Brazil. Ministério da Saúde. Instituto Nacional do Câncer [INCA]. Control of Breast Cancer: Consensus Document. Rio de Janeiro: INCA 2004.

5. Brito C, Portela MC, Vasconcellos MTL. SUS oncological care to women with breast cancer in Rio de Janeiro. Rev Public Health, 2005; 39(6): 874- 81.

6. Brito C, Portela MC, Vasconcellos MTL. Survival of women treated for breast cancer in Rio de Janeiro. Rev S Pub, 2009; 43(3): 481-9.

7. Shang EC, Weiss PS, Kaehler G. The Influence of early supplementation of parenteral on nutrition quality of life and body composition in patients with advanced cancer. J Par Ent Nutr, 2006; 30(3): 222-30.

8. Giglio A. A quimioterapia adjuvante para cancer de mama engorda? Rev Assoc Med Bras, 2004; 50(3): 238-45.

9. Giglio A. A quimioterapia adjuvante para câncer de mama engorda? Rev Assoc Med Bras, 2004; 50(3): 32-9.

10. Neugut Al, Matthew M, Xiaoyan W, Russell M, Jacobson JS, Wei-Yann T, Grann VR, Dawn LH. Duration of adjuvant chemotherapy for colon cancer and survival among the elderly. J Clin Oncol, 2006; 24(15): 2368-75.

11. Perez E, Muss HB. Optimizing adjuvant chemotherapy in early-stage of breast cancer. Oncology, 2005; 19(4): 1759-67.
12. Novaes MRCG, Fortes RC. Antitumor effects of edible Agaricaceae mushrooms. Nutrition Brazil, 2005; 4(4): 15-9.

13. Novaes MRCG, Novaes LCG. Drug-nutrient in edible mushrooms and other basidiomycetous Agaricales. Rev Bras Nutr Clin, 2005; 20(3): 181-7.

14. Fortes RC, Novaes MRCG. Effects of dietary supplementation with Agaricales mushrooms and other fungi in medicinal therapy against cancer. RBC, 2006; 52(4): 363-71.

15. Novaes MRCG, Fortes R, Melo A, Recova V. Alterations on the metabolism of lipids in postsurgery patients suffering from colorectal cancer supplemented with Agaricus sylvaticus fungus. Proceedings of the 27th International Congress of ESPEN and Clinical Nutrition. August, 27-30, Brussels, Belgium. 2005.

16. Novaes MRCG, Novaes LCG, Recova V, Melo A. Evalution of acute toxicity of edible mushroom Agaricus sylvaticus. Proceedings of the 27th International Congress of ESPEN and Clinical Nutrition. August, 27-30, Brussels, Belgium. 2005.

17. Novaes MRG, Novaes Garcez LCG, Melo A, Recova V. Effects of administration of Agaricus sylvaticus fungi on hematological and immunological systems of rats with Walker carcinoma-256. Fundamental \& Clinical Pharmacology, 2004; 18 (S1): 125-9.

18. Takimoto HD, Wakita KK, Kumazawa Y. Potentiation of cytotoxic activity in naive and tumor-bearing mice by oral administration of hot-water extracts from Agaricus braze f ruiting bodies. Biol Pharm Bull, 2004; 27: 404-6.

19. Chu KKW, Ho SSS, Chow AHL. Coriolus versicolor: a medicinal mushroom with promising immunotherapeutic values. J Clin Pharmacol, 2002; 42: 976-84.

20. Soh CSR, Phung HS, Ye JJ, Kwok SL, Shroder GE, Belury M, Adams LS. Williams D. Anti-aromatase activity of phytochemicals in white button mushrooms (Agaricus bisporus). Cancer Res, 2006; 66: 12026-34. 
21. Grube JB, Eng ET, Kao YC, Kwon A, Chen S. White button mushroom phytochemicals inhibit aromatase activity and breast cancer cell proliferation. J Nutr, 2001; 131: 3288-93.

22. Shang EC, Weiss PS, Kaehler G. The influence of early supplementation of parenteral on nutrition quality of life and body composition in patients with advanced cancer. J Par Ent Nut, 2006; 30(3): 222-30.

23. Fang $\mathrm{N}, \mathrm{Li} \mathrm{Q}, \mathrm{Yu} \mathrm{S}$, Zhang J, He L, Ronis MJ, Badger TM. Inhibition of growth and induction of apoptosis in human cancer cell lines by an ethyl acetate fraction from shiitake mushrooms. J Altern Complement Med, 2006; 12(2): 125-32.

24. Takaku T, Kimura $\mathrm{Y}$, Okuda H. Isolation of an antitumor compound from Agaricus blazei Murill and Its mechanism of action. Journal of Nutrition, 2001; 131: 1409-13.

25. Jedinak A, Sliva D. Pleorotus ostreatus inhibits proliferation of human breast cancer and colon cancer cells through p53-dependent as well as p53independent pathway. Inter J Oncol, 2008; 33(6): 1307-13.

26. Hetland G, Johnson E, Lyberg T, Bernardshaw S, Tryggestad AM, Grinde B. Effects of the medicinal mushroom Agaricus blazei Murill on immunity, infection and cancer. Scand J Immunol, 2008; 68(4): 363-70.

27. Ajith TA, Janardhanan KK. Indian Medicinal Mushrooms as a source of antioxidant and antitumor agents. J Clin Biochem Nutr, 2007; 40(3): 157-62.

28. Bernadshaw S, Lyberg T, Hetland G, Johnson E. Effect of an extract of the mushroom Agaricus blazei Murill on expression of adhesion molecule and production of reactive oxygen species in monocytes and granulocytes in human whole blood ex vivo. APMIS. 2007; 115(6): 719-25.

29. Talorete TP, Isoda H, Maekawa T. Agaricus blazei (class Basidiomycotina) aqueous extract enhances the expression of c-Jun protein in MCF-7 cells. J Agric Food Chem. 2002; 50(18): 5162-6.
30. Hong SA, Kim K, Nam SJ, Kong G, Kim MKA casecontrol study on the dietary intake of mushrooms and breast cancer risk among Korean women. Int J Cancer. 2008; 122(4th): 919-23.

31. Fortes RC, Novaes MRCG. The impact of dietary supplementation with Agaricus sylvaticus on immune function of post-surgical patients suffering from colorectal cancer: a randomized, double blind, placebo-controlled clinical trial. Proceedings of the I. World Congress of Public Health Nutrition / VII National Congress of the Spanish Society of Community Nutrition. Public Health Nutrition, 28- 30 September 2006, Barcelona, Spain: NS 2006.

32. Dolby V. In maitake mushroom extract froom is important in anti-cancer. Better Nutrition. 1997; 59(8): 38.

33. See D. Mason St. Roshan R. Increased tumor necrosis factor alpha (TNF-alpha) and natural killer cell (NK) function using an integrative approach in late stage cancers. Immunol Invest. 2002; 31: 137-53.

34. Gennari J, Gennari M, Felippe J. The Agaricus sylvaticus increases the number of natural killer cells in cancer patients. J Com Med. 2001; 7: 42-5.

35. Gennari JL,Veronesi R, Gennari M. Use of Agaricus sylvaticus as a supplement therapy in patients with breast cancer and lung metastasis. Revista Brasileira de Medicina. 2002; 59(7): 237-8.

36. Aguiar MRS. Impact of Food Supplementation on Hematologic Toxicity And Quality of Life and Women with Breast Cancer under Adjuvant Chemotherapy Regimen. Thesis [Master's Degree - Science and Environmental Health] Catholic University of Goiás, 2008.

37. Padilha MM, Avila AA, Sousa PJ, Cardoso LG, Perazzo FF, Carvalho JC. Anti-inflammatory activity of aqueous and alkaline extracts from mushrooms (Agaricus blazei Murill). J Med Food. 2009; 12(2): 59-64. 